University of Nebraska - Lincoln

DigitalCommons@University of Nebraska - Lincoln

Faculty Publications in Food Science and Technology

Food Science and Technology Department

July 2002

\title{
Factors affecting the determination of threshold doses for allergenic foods: How much is too much?
}

\author{
Steve L. Taylor \\ Lincoln, Nebraska, staylor2@unl.edu \\ Susan L. Hefle \\ Lincoln, Nebraska \\ Carsten Bindslev-Jensen \\ Odense, Denmark \\ S. Allan Bock \\ Boulder, Colorado
}

A. Wesley Burks Jr.

Little Rock, Ark

See next page for additional authors

Follow this and additional works at: https://digitalcommons.unl.edu/foodsciefacpub

Part of the Food Science Commons

Taylor, Steve L.; Hefle, Susan L.; Bindslev-Jensen, Carsten; Bock, S. Allan; Burks, A. Wesley Jr.; Christie, Lynn; Hill, David J.; Host, Arne; Hourihane, Jonathan O'B.; Lack, Gideon; Metcalfe, Dean D.; MoneretVautrin, Denise Anne; Vadas, Peter A.; Rance, Fabienne; Skrypec, Daniel J.; Trautman, Thomas A.; Malmheden Yman, Ingrid; and Zeiger, Robert S., "Factors affecting the determination of threshold doses for allergenic foods: How much is too much?" (2002). Faculty Publications in Food Science and Technology. 37.

https://digitalcommons.unl.edu/foodsciefacpub/37

This Article is brought to you for free and open access by the Food Science and Technology Department at DigitalCommons@University of Nebraska - Lincoln. It has been accepted for inclusion in Faculty Publications in Food Science and Technology by an authorized administrator of DigitalCommons@University of Nebraska - Lincoln. 


\section{Authors}

Steve L. Taylor, Susan L. Hefle, Carsten Bindslev-Jensen, S. Allan Bock, A. Wesley Burks Jr., Lynn Christie, David J. Hill, Arne Host, Jonathan O'B. Hourihane, Gideon Lack, Dean D. Metcalfe, Denise Anne MoneretVautrin, Peter A. Vadas, Fabienne Rance, Daniel J. Skrypec, Thomas A. Trautman, Ingrid Malmheden Yman, and Robert S. Zeiger 


\section{Rostrum}

\section{Factors affecting the determination of threshold doses for allergenic foods: How much is too much?}

Steve L. Taylor, PhD, a Susan L. Hefle, PhD, a Carsten Bindslev-Jensen, MD, ${ }^{b}$

S. Allan Bock, MD,c A. Wesley Burks, Jr, MD,d Lynn Christie, RD,d David J. Hill, MD, e

Arne Host, MD, f Jonathan O’B. Hourihane, MD,g Gideon Lack, MD, ${ }^{\text {h }}$

Dean D. Metcalfe, MD, i Denise Anne Moneret-Vautrin, MD, i Peter A. Vadas, MD,k

Fabienne Rance, MD,' Daniel J. Skrypec, PhD, m Thomas A. Trautman, PhD,n

Ingrid Malmheden Yman, PhD, ${ }^{\circ}$ and Robert S. Zeiger, MDp Lincoln, Neb, Odense, Den-

mark, Boulder, Colo, Little Rock, Ark, North Melbourne, Australia, Southampton and London,

United Kingdom, Bethesda, Md, Nancy and Toulouse, France, Toronto, Ontario, Canada, Glen-

view, Ill, Minneapolis, Minn, Uppsala, Sweden, and San Diego, Calif

Background: Ingestion of small amounts of an offending food can elicit adverse reactions in individuals with IgE-mediated food allergies. The threshold dose for provocation of such reactions is often considered to be zero. However, because of various practical limitations in food production and processing, foods may occasionally contain trace residues of the offending food. Are these very low, residual quantities hazardous to allergic consumers? How much of the offending food is too much? Very little quantitative information exists to allow any risk assessments to be conducted by the food industry.

Objective: We sought to determine whether the quality and quantity of existing clinical data on threshold doses for commonly allergenic foods were sufficient to allow consensus to be

From aUniversity of Nebraska, Food Allergy Research and Resource Program, Lincoln; ' bdense University Hospital, Department of Dermatology, Odense; cBoulder Valley Asthma \& Allergy Clinic, Boulder; dArkansas Children's Hospital, Pediatric Allergy \& Immunology, Little Rock; ethe Department of Allergy, Melbourne Children's Hospital, North Melbourne; fOdense University Hospital, Department of Pediatrics, Odense; sAllergy and Inflammation Sciences Division, Southampton General Hospital, Southampton; ${ }^{1}$ the Department of Pediatric Allergy and Immunology, St Mary's Hospital, London; 'Laboratory of Allergic Diseases, National Institute of Allergy and Infectious Diseases, NIH, Bethesda; ithe Department of Clinical Immunology and Allergology, Hopital Central, Nancy; kthe Division of Allergy and Clinical Immunology, St Michael's Hospital, University of Toronto, Toronto; 'the Department of Allergologie, Hopital des Enfants, Toulouse; ${ }^{\mathrm{m} K r a f t}$ Foods, Inc, Glenview; ${ }^{\mathrm{n}}$ General Mills, Inc, Minneapolis; National Food Administration, Research \& Development, Uppsala; and PKaiser Permanente Medical Center, San Diego, and the Department of Pediatrics, University of California-San Diego.

Sponsored by the Food Allergy Research and Resource Program.

Received for publication July 12, 2001; revised September 27, 2001; accepted for publication September 27, 2001.

Reprint requests: Steve L. Taylor, PhD, University of Nebraska, Food Allergy Research \& Resource Program, 143 Food Industry Bldg, Lincoln, NE 68583-0919.

$1 / 88 / 120564$

doi: $10.1067 /$ mai.2002.120564 reached on establishment of threshold doses for specific foods. Methods: In September 1999, 12 clinical allergists and other interested parties were invited to participate in a roundtable conference to share existing data on threshold doses and to discuss clinical approaches that would allow the acquisition of that information.

Results: Considerable data were identified in clinical files relating to the threshold doses for peanut, cows' milk, and egg; limited data were available for other foods, such as fish and mustard.

Conclusions: Because these data were often obtained by means of different protocols, the estimation of a threshold dose was very difficult. Development of a standardized protocol for clinical experiments to allow determination of the threshold dose is needed. (J Allergy Clin Immunol 2002;109:24-30.)

Key words: Allergy, food, challenge, threshold dose

How much is too much? Allergists know that exposure to small quantities of the offending food can elicit adverse reactions, sometimes even severe reactions, in individuals with IgE-mediated food allergies. ${ }^{1,2}$ For all practical purposes, allergists have always assumed that the threshold dose for the offending food was zero. When advising patients to adhere to specific avoidance diets, such advice is probably prudent.

\section{FOOD INDUSTRY PREDICAMENT}

A zero tolerance for the offending food creates enormous practical problems for the food industry. From a practical economic perspective, the food industry must manufacture many different food products within the same manufacturing facility. In some facilities several hundred different products are manufactured within a single building. In such situations trace residues of a specific food could come into contact with another food being manufactured in the same facility. ${ }^{3,4}$ Furthermore, the 


\section{Abbreviations used \\ DBPCFC: Double-blind, placebo-controlled food challenge \\ LOAEL: Lowest-observed-adverse-effect level \\ NOAEL: No-observed-adverse-effect level \\ SBPCFC: Single-blind, placebo-controlled food challenge}

food industry often uses shared equipment to manufacture related food products. A few examples include ice cream and sorbet, cookies or other baked goods with varying formulations, egg-free and egg-containing pastas, and chocolate confections with differing ingredients. When one product containing a food allergen is manufactured on shared equipment just before another product that does not contain the same food allergen, the equipment must be scrupulously cleaned between manufacturing of the 2 products. This is necessary to avoid the possibility that potentially hazardous residues of an allergenic food will enter a product that is not supposed to contain that ingredient. But how clean is clean enough?

The chains of distribution of foods and their ingredients can be quite complex in today's worldwide food industry. Opportunities exist for food products to come into contact with allergenic foods or ingredients throughout this complex supply chain. As an example, soybeans and corn are often harvested on the same Midwestern US farms at the same time of the year. Harvesting equipment, transportation vehicles, and storage facilities are often shared. Corn, which is not typically an allergenic food, can become contaminated with residual soybeans, a more common allergenic food. This contamination can be carried through to processed corn products. Are low levels of residual soybeans in corn products potentially harmful to consumers with soybean allergy?

These situations illustrate the plight faced by the food industry in their efforts to protect the well-being of allergic consumers. The farm-to-table food production, processing, and distribution chain needs better information on the threshold dose for provocation of allergic reactions to foods. The proliferation of precautionary labels (eg, "may contain peanuts") is an industry response to the existing uncertainty. Without information on threshold doses, it is difficult for the food industry to conduct risk assessments and to focus their quality-control efforts where the benefit to the allergic consumer would be the greatest.

\section{CLINICAL CONSIDERATIONS}

The medical community would also benefit from increased information regarding threshold doses. These same situations described above create questions for allergists and their patients with food allergy that cannot be adequately answered without some knowledge of the threshold dose below which reactions are unlikely to occur.

Evidence is needed on the threshold dose for the offending food among sensitive individuals and the level of the offending food present in the food product under consideration to conduct an assessment of the risk posed by trace residues of allergenic foods in other food prod- ucts. The threshold dose might best be defined as the lowest amount of the offending food that would elicit mild, objective symptoms (eg, mild urticaria, erythema, and oral angioedema) in the most sensitive individuals. The amount of the offending food needed to elicit symptoms is variable, possibly over an order of magnitude or more between different individuals with the same type of food allergy. ${ }^{5}$ Many factors contribute to this variability. Intraindividual variability probably also occurs as a result of potentiating factors, such as exercise, alcohol, and acetylsalicylic acid. ${ }^{6}$ Also, the threshold doses for different allergenic foods (eg, peanuts and eggs) are not necessarily equal.

\section{EPISODES ASSOCIATED WITH UNDECLARED ALLERGENS IN FOODS}

Presently, very little information exists on the basis of which to estimate the threshold dose for specific allergenic foods. Anecdotal reports indicate that reactions have occurred from such incidental contacts as opening packages of the offending food, wiping counters or tables having peanut residues, inhaling vapors from cooking of the food, use of shared utensils, and kissing the lips of someone who has eaten the offending food. ${ }^{7}$ Although such anecdotal reports confirm that ingestion of very small amounts of allergenic foods may provoke allergic reactions in some sensitive individuals, they do not provide quantitative information on the lowest provoking dose.

More quantitative estimates of the lowest provoking dose can be derived from actual allergic reactions occurring in patients from whom careful histories are taken regarding the amount of the offending food that was ingested. In the case of foods contaminated with trace residues of an allergenic food, such histories must be coupled with a quantitative analysis of the amount of the allergenic food found in the implicated product. Comparatively few such estimates have been made involving a rather small number of individuals. This is probably because of the lack of simple methods for the analysis of the implicated food product for residues of commonly allergenic foods. In the investigation of a case involving frozen Tofutti containing undeclared milk residues, the ingestion of an amount of tofutti equivalent to $2.5 \mathrm{~mL}$ of milk elicited a reaction. ${ }^{2}$ In the investigation of a case involving hot dogs containing undeclared milk residues, the ingestion of an amount of the hot dogs equivalent to $0.3 \mathrm{~mL}$ of milk elicited reactions in several children. ${ }^{2} \mathrm{In}$ a case involving the ingestion of sorbet manufactured on shared equipment with ice cream, a child with milk allergy reacted after eating an unknown amount of sorbet containing $0.52 \%$ (wt/wt) milk protein. ${ }^{4}$ In a similar episode a child with milk allergy apparently reacted after eating approximately 4 to $6 \mathrm{oz}$ of sorbet containing less than $200 \mu \mathrm{g}$ of whey protein. ${ }^{1}$ Malmheden Yman et al ${ }^{8}$ reported a series of incidents related to inadvertent or unexpected exposure to allergenic foods that resulted in allergic reactions among sensitive individuals. Many of these incidents involved exposure to small quantities of 
the offending food, including milk in 9 incidents at levels ranging from $0.04 \%$ to $1.1 \%$ (wt/wt), egg in 3 incidents at levels ranging from $0.003 \%$ to $0.16 \%$ (wt/wt), wheat gluten in 2 incidents at levels ranging from $0.3 \%$ to $1.3 \%(\mathrm{wt} / \mathrm{wt})$, soy protein in 2 incidents at levels ranging from $0.5 \%$ to $7.0 \%$ (wt/wt), and hazelnut in 1 incident at a level of $0.2 \%$ (wt/wt). Quantitative exposure information was available in several of these cases. Fatal anaphylaxis occurred in a consumer with milk allergy after eating approximately $100 \mathrm{~g}$ of a sausage product containing $0.06 \%$ undeclared casein that equated to 60 mg of casein. ${ }^{8}$ An asthmatic reaction occurred in an individual with hazelnut allergy after ingestion of about 3 to $6 \mathrm{~g}$ of a chocolate confection containing $0.2 \%$ of undeclared hazelnut that equated to 6 to $12 \mathrm{mg}$ of hazelnut. 8 Although such episodes reveal the hazards posed by undeclared residues of allergenic foods contaminating other foods, they are not particularly suitable for establishing the lowest provoking dose. For example, the circumstances of exposure, including the amount and type of foods eaten during the episode, can only be determined anecdotally. Also, the reliability of the analytic results can be questioned because validated, collaboratively studied, standard methods are not yet available.

\section{CLINICAL APPROACHES TO THRESHOLD DOSE ESTIMATION}

The best estimates of the threshold dose for various allergenic foods can be obtained from controlled clinical challenge trials. In only a few cases were such trials intended specifically to determine the threshold dose. ${ }^{5,9}$ More frequently, challenges have been conducted for diagnostic purposes rather than for determining the lowest provoking dose. However, typical protocols involve starting at doses that are one half or less of the amount of the offending food estimated by the patient to provoke symptoms. ${ }^{10}$

Because low doses of allergenic foods are sometimes used in the diagnosis of food allergies, especially in patients with histories of serious allergic reactions, the possibility exists that data on the threshold doses for common allergenic foods might exist in certain allergy clinics. Consequently, in September 1999, the Food Allergy Research and Resource Program at the University of Nebraska, with sponsorship from the food industry, convened a roundtable conference entitled "Threshold Doses for Allergenic Foods: How Much Is Too Much?"

\section{RESULTS OF THE ROUNDTABLE}

Several clinical groups did possess potentially useful information relating to the threshold doses for commonly allergenic foods derived from the results of past doubleblind, placebo-controlled, food challenges (DBPCFCs) used for diagnostic purposes. The most useful data were available on peanuts, eggs, and cows' milk and will be reported here. Some data were also available on fish and mustard seed. Data were also available for soybeans, wheat, sesame seed, tree nuts, and crustaceans, but the number of patients tested was too few, and in some cases, the nature of the challenge materials was not precisely known (eg, the variety of tree nuts, the form of soybean, and the method of processing or species of crustacean).

Table I contains the results of the accumulated data on the lowest provoking doses in DBPCFCs for the various investigators involved in the roundtable conference for peanuts, eggs, and cows' milk. For peanut, results were shared on DBPCFCs (and some single-blind, placebocontrolled food challenges [SBPCFCs] and open challenges) of 306 patients. The lowest provoking dose was 1 mg of peanut, which was seen with 4 patients; all of these patients were from the clinic of Dr Fabienne Rance in France. The range of lowest provoking doses for these patients was $1 \mathrm{mg}$ to $5 \mathrm{~g}$. For eggs, results were shared on DBPCFCs (and some SBPCFCs and open challenges) of 281 patients. The lowest provoking dose was $1 \mathrm{mg}$ of liquid whole egg, which was seen with 2 patients, both from the clinic of Dr Rance in France. The range of lowest provoking doses for these patients was $1 \mathrm{mg}$ to $5 \mathrm{~g}$. For cows' milk, the results are much more difficult to interpret because several different forms of cows' milk were used in the challenges: liquid cows' milk, nonfat dry milk, and infant formula. For cows' milk, results were shared on DBPCFCs (and a few SBPCFCs and open challenges) of 299 patients. The lowest provoking dose was $0.02 \mathrm{~mL}$ of milk, which was seen in 21 patients; all of these patients were from the clinic of Dr David Hill from Australia. The range of lowest provoking doses for these patients was $0.02 \mathrm{~mL}$ to greater than $100 \mathrm{~mL}$. For fish, the lowest provoking dose was $5 \mathrm{mg}$ of either cod or herring, as determined from the results of DBPCFCs (and some SBPCFCs) on 32 patients. However, the species of fish used in these challenges were variable, and this appeared to affect the results, as noted from comparative information obtained on 14 patients for 4 different species by Dr Carsten Bindslev-Jensen in Denmark. Fifteen individuals with mustard allergy have been evaluated by means of DBPCFCs in France, and the most sensitive individual reacted to $1 \mathrm{mg}$ of ground mustard seed. To apply this information in the context of a typical serving of food containing undeclared residues of an allergenic food, $1 \mathrm{mg}$ of an allergenic food in a typical $50-\mathrm{g}$ serving would be equivalent to $20 \mathrm{mg}$ of allergenic food per kilogram of the ingested food product $(20 \mathrm{ppm})$.

\section{DISCUSSION}

Clearly, sufficient results are available to conclude that the threshold doses for commonly allergenic foods are finite, measurable, and above zero. However, attempting to reach consensus on the threshold doses for peanut, egg, cows' milk, fish, and mustard on the basis of the existing data would probably be premature for a number of reasons. The number of patients who have been subjected to DBPCFCs with low doses of the offending food is probably sufficient to estimate the threshold dose at least for peanut, egg, and cows' milk. However, the nature of the data suggests that it may be premature to 
TABLE I. Lowest provoking dose for commonly allergenic foods

\begin{tabular}{|c|c|c|c|c|c|c|}
\hline & \multirow{2}{*}{$\begin{array}{l}\text { Physician } \\
\text { or group }\end{array}$} & \multirow{2}{*}{$\begin{array}{c}\text { No. of } \\
\text { patients }\end{array}$} & \multirow{2}{*}{$\begin{array}{l}\text { Nature of } \\
\text { challenges } \\
\text { (DB or SB) }\end{array}$} & \multicolumn{2}{|c|}{ Lowest provoking dose } & \multirow[b]{2}{*}{ Form } \\
\hline & & & & Amount of food & Amount of protein & \\
\hline \multirow[t]{10}{*}{ Peanut } & Hourihane & 14 & DB & $4.3 \mathrm{mg}$ & $2 \mathrm{mg}$ & $\mathrm{PF}+$ \\
\hline & National Jewish & 3 & DB & $10 \mathrm{mg}$ & $2.5 \mathrm{mg}$ & Ground peanut \\
\hline & Bindslev-Jensen and Mortz & 5 & DB & $160 \mathrm{mg}$ & $40 \mathrm{mg}$ & Ground peanut \\
\hline & Bock & 69 & DB & $50 \mathrm{mg}$ & $1.25 \mathrm{mg}$ & Ground peanut \\
\hline & Burks and Christie & 10 & DB & $400 \mathrm{mg}$ & $100 \mathrm{mg}$ & $\mathrm{PB}$ \\
\hline & Lack & 6 & SB & $500 \mathrm{mg}$ & $125 \mathrm{mg}$ & Ground peanut \\
\hline & Hill & 100 & Open & 1 drop of PB & $6 \mathrm{mg}$ & PB \\
\hline & Rance & 74 & DB & $1 \mathrm{mg}$ & $0.25 \mathrm{mg}$ & Ground peanut \\
\hline & Moneret-Vautrin \#1 & 28 & DB or SB & $5 \mathrm{mg}(\mathrm{SB}), 10 \mathrm{mg}(\mathrm{DB})$ & $1.25 \mathrm{mg}, 2.5 \mathrm{mg}$ & Ground peanut \\
\hline & Moneret-Vautrin \#2 & 9 & DB or SB & $265 \mathrm{mg}$ & $66 \mathrm{mg}$ & Ground peanut \\
\hline \multirow[t]{9}{*}{ Egg } & Moneret-Vautrin \#1 & 19 & DB & $2 \mathrm{mg}$ & $0.2 \mathrm{mg}$ & $\mathrm{EW} \S$ \\
\hline & Moneret-Vautrin \#2 & 8 & DB or SB & $265 \mathrm{mg}$ & $26.5 \mathrm{mg}$ & EW\& \\
\hline & Bock & 91 & DB & $20 \mathrm{mg}$ & & $\begin{array}{c}\text { Dried EW or } \\
\text { whole egg }\end{array}$ \\
\hline & Bindslev-Jensen and Norgaard & 7 & DB & $5 \mathrm{mg}$ & $0.65 \mathrm{mg}$ & $\begin{array}{l}\text { Whole eggII } \\
\text { (raw) }\end{array}$ \\
\hline & Burks and Christie & 25 & DB & $400 \mathrm{mg}$ & $200 \mathrm{mg}$ & $\begin{array}{l}\text { Dried whole } \\
\text { egg }\end{array}$ \\
\hline & Hill & 100 & Open & $0.02 \mathrm{~mL}$ & $2 \mathrm{mg}$ & EW (raw) \\
\hline & Rance & 38 & DB & $1 \mathrm{mg}$ & $0.13 \mathrm{mg}$ & $\begin{array}{l}\text { Whole egg } \\
\text { (raw) }\end{array}$ \\
\hline & Lack & 13 & SB & $100 \mathrm{mg}$ & $10 \mathrm{mg}$ & EW (cook) \\
\hline & Lack & 5 & SB & $200 \mathrm{mg}$ & $20 \mathrm{mg}$ & EW (raw) \\
\hline \multirow[t]{10}{*}{ Milk } & Bindslev-Jensen and Norgaard & 3 & DB & $5000 \mathrm{mg}$ & $180 \mathrm{mg}$ & Milk \\
\hline & Hill & 100 & Open & $0.02 \mathrm{~mL}$ & $0.6 \mathrm{mg}$ & Milk \\
\hline & Bock & 66 & DB & $2 \mathrm{~mL}$ & $67 \mathrm{mg}$ & NFDM \\
\hline & Burks and Christie & 21 & DB & $400 \mathrm{mg}$ & $140 \mathrm{mg}$ & NFDM \\
\hline & Rance & 31 & DB & $0.5 \mathrm{~mL}$ & $15 \mathrm{mg}$ & Milk \\
\hline & Lack & 6 & SB & $5 \mathrm{~mL}$ & $150 \mathrm{mg}$ & Milk \\
\hline & Moneret-Vautrin \#1 & 6 & DB or SB & $1 \mathrm{~mL}(\mathrm{DB}), 5 \mathrm{~mL}(\mathrm{SB})$ & $30 \mathrm{mg}, 150 \mathrm{mg}$ & Milk \\
\hline & Zeiger & 56 & DB & $0.1 \mathrm{~mL}$ & $1.5 \mathrm{mg}$ & Formula\# \\
\hline & Host & $15-A^{* *}$ & DB & $5 \mathrm{~mL}$ & $75 \mathrm{mg}$ & Formula\# \\
\hline & & $15-I * *$ & DB & $5 \mathrm{~mL}$ & $75 \mathrm{mg}$ & Formula\# \\
\hline \multirow[t]{7}{*}{ Fish } & Rance & 6 & DB & $16 \mathrm{mg}$ & Unknownt† & Minced fish \\
\hline & Moneret-Vautrin \#1 & 4 & DB or SB & $15 \mathrm{mg}$ (SB), $65 \mathrm{mg}$ (DB) & ) Unknown & Minced fish \\
\hline & Bindslev-Jensen and Hansen守宗 & 14 & DB & $5 \mathrm{mg}$ & Unknown & Minced cod \\
\hline & Bindslev-Jensen and Hansen芒 & 14 & DB & $500 \mathrm{mg}$ & Unknown & $\begin{array}{l}\text { Minced } \\
\text { mackerel }\end{array}$ \\
\hline & Bindslev-Jensen and Hansen & 14 & DB & $5 \mathrm{mg}$ & Unknown & Minced herring \\
\hline & Bindslev-Jensen and Hansen & 14 & DB & $6000 \mathrm{mg}$ & Unknown & Minced plaice \\
\hline & Bock & 8 & DB & $200 \mathrm{mg}$ & Unknown & Minced fish \\
\hline Mustard & Rance & 15 & DB & $1 \mathrm{mg}$ & $0.3 \mathrm{mg}$ & $\begin{array}{l}\text { Ground mustard } \\
\text { seed }\end{array}$ \\
\hline
\end{tabular}

$D B$, Double-blind; $S B$, single-blind; $P F$, Peanut flour; $P B$, peanut butter; $E W$, egg white; $N F D M$, nonfat dry milk.

$\leftarrow$ Peanut flour is assumed to contain $50 \%$ protein unless the value is specifically known.

†Work conducted also with Charlotte Mortz, PhD.

\$Liquid egg white has an average protein content of $10 \%$; dried egg white has an average protein content of $90 \%$. Work conducted also with Astrid Norgaard, $\mathrm{PhD}$.

WWhole egg has an average of $13 \%$ protein on a liquid basis and $50 \%$ protein on a dry basis.

\#Cows' milk formula is estimated to contain $15 \mathrm{~g}$ of milk protein per liter.

*Cows' milk allergy $(A)$ or cows' milk intolerance $(I)$.

$+\rightarrow T h e$ protein content of the fish was not measured and may have been variable on the basis of the type of fish used.

țWork conducted also with Tine Hansen, $\mathrm{PhD}$.

attempt such an estimate. Because the experiments were usually designed for diagnostic purposes rather than for determination of the threshold dose, several experimental design elements may contribute to the difficulty in reach- ing consensus on the basis of the current data set. Certainly, a variety of different protocols were used in the various clinics where the data were generated. Thus commingling of the data may not be entirely appropriate. 
TABLE II. Typical amounts of protein in challenge vehicles

\begin{tabular}{|c|c|c|c|c|c|}
\hline \multirow[b]{2}{*}{ Food-challenge material } & \multicolumn{5}{|c|}{ Typical amount of protein contained* } \\
\hline & $\mathbf{L}$ & $\mathbf{m} \mathbf{L}$ & Fluid oz & $\mathbf{g}$ & $\mathbf{o z}$ \\
\hline Whole milk & $30-36 \mathrm{~g}$ & $30-36 \mathrm{mg}$ & $880-1066 \mathrm{mg}$ & & \\
\hline Infant formula (milk protein) & $15 \mathrm{~g}$ & $15 \mathrm{mg}$ & $444 \mathrm{mg}$ & & \\
\hline NFDM & & & & $350 \mathrm{mg}$ & $9.9 \mathrm{~g}$ \\
\hline Egg white, liquid & $10 \mathrm{~g}$ & $10 \mathrm{mg}$ & $296 \mathrm{mg}$ & & \\
\hline Whole egg, liquid & $13 \mathrm{~g}$ & $13 \mathrm{mg}$ & $385 \mathrm{mg}$ & & \\
\hline Egg white, dried & & & & $900 \mathrm{mg}$ & $25.5 \mathrm{~g}$ \\
\hline Whole egg, dried & & & & $500 \mathrm{mg}$ & $14.2 \mathrm{~g}$ \\
\hline Peanut butter & & & & $250 \mathrm{mg}$ & $7.1 \mathrm{~g}$ \\
\hline Peanut flour, defatted & & & & $500 \mathrm{mg}$ & $14.2 \mathrm{~g}$ \\
\hline
\end{tabular}

NFDM, Nonfat dry milk.

*Units of measure, such as drops or teaspoons (for dried or paste materials), can be difficult to quantify.

The major reason for not estimating a threshold dose on the basis of the available data is that the no-observedadverse-effect level (NOAEL) was not established for the vast majority of the patients involved in these trials. In risk assessments used by the World Health Organization, the Food and Agriculture Organization of the United Nations, and various worldwide regulatory agencies to establish acceptable daily intakes (virtually safe doses) for food additives, the NOAEL is first established on the basis of research with experimental animals or observations on human subjects. ${ }^{11}$ Uncertainty factors are then applied, on the basis of such factors as the need to extrapolate from experimental animals to human subjects, to estimate the acceptable daily intake. ${ }^{12}$ Regulatory toxicologists often apply an uncertainty factor of 10 when attempting to extrapolate data from experimental animals to human subjects. Another factor of 10 is often applied to account for possible human-to-human variability. Thus the NOAEL generated from a toxicologic study in rats or mice is typically divided by 100 to estimate a safe dose for human subjects. ${ }^{13}$ In attempting to estimate a threshold dose for allergic individuals from the available clinical data, a key issue would be the magnitude of the uncertainty factor to use in the risk assessment. A factor of 10 would generally be considered appropriate in most situations in which experimental data are available on human subjects, but the suitability of this uncertainty factor for application to the determination of threshold doses for allergenic foods requires extensive discussion.

In the data presented at this roundtable conference, the lowest provoking dose for each individual patient was known. For risk-assessment purposes, this dose would be the lowest-observed-adverse-effect level (LOAEL). Because the DBPCFCs were being performed for diagnostic purposes, only the LOAEL was recorded. For the purposes of estimating a threshold dose, it would be preferable to have information on the NOAEL. The highest dose in the DBPCFCs that did not elicit an adverse reaction should be known to determine the NOAEL. However, that information was not generally available because the most sensitive patients involved in these challenge trials reacted to the first and lowest dose used. This dose is thus the LOAEL, and uncertainty exists about how much less of the offending food would be required to reach the NOAEL. Although the LOAEL could be used to estimate the threshold dose, that would introduce an additional uncertainty factor of indeterminate magnitude. Because an uncertainty factor would need to be applied to estimate the NOAEL from the LOAEL and because no consensus has been reached on the size of that uncertainty factor, no attempt was made at this time to estimate a NOAEL for peanut, egg, or milk.

Other factors also argue against establishment of a threshold dose at this time. One question involves whether the patients selected for DBPCFCs are representative of the entire population of individuals with allergies to that specific food. Most physicians acknowledge excluding some of the most seriously affected patients (ie, those with histories of anaphylactic shock) from challenge trials. It could be argued that these patients may be among the very most sensitive. Therefore if using data on the basis of an incomplete set of the relevant patients, some adjustments might need to be made with uncertainty factors. In the data presented here, some physicians excluded severely affected patients, whereas others did not. In consideration of the existing data on threshold doses for allergenic foods, the critical debate might center around whether the usual 10-fold uncertainty factor would be sufficient to account for the most sensitive individuals in the population, who may not have been included in the clinical experiments. Would individuals exist who were more than 10 times as sensitive as the most sensitive individual in the tested group?

The age and body weight of the patients may also be a consideration. The lowest provoking doses expressed in Table I are presented as milligrams of protein or food. Some of the challenges were conducted on infants and young children, whereas others were conducted on adults. Should provoking doses be expressed on a weight basis (eg, milligram per kilogram) of body weight?

The nature of the challenge material is another factor creating some uncertainty. The standardization of challenge materials would certainly ease the comparative interpretation of the results. For peanut, most clinicians used ground peanuts as their challenge material and expressed their results as milligrams of peanut. However, 
in one case peanut butter was used. In another case ${ }^{5}$ peanut flour was used. In such cases assumptions must be made in expressing the challenge doses in milligrams of peanut or peanut protein. For eggs, most of the investigators used egg white as the challenge material, although some used whole egg. One investigator used both raw and cooked egg white. In Table I the results were converted to milligrams of egg protein to obtain a more consistent basis for comparison. With cows' milk, the situation is even more confusing. Liquid milk, nonfat dry milk, and infant formula are used as challenge materials. In Table I the data were converted to milligrams of milk protein, but the conversion required some important assumptions regarding appropriate conversion factors. Table II provides a summary of the differing amounts of protein found in various forms of cows' milk, egg, and peanut. These differences highlight the interpretive problems associated with the use by various clinicians of different forms of the specific foods in the challenge. Standardization of this aspect would be helpful in obtaining easily comparable data from different clinics.

The specific allergen content of the challenge materials may also affect the estimation of the threshold dose. Peanut, cows' milk, and egg contain multiple allergens, ${ }^{14-16}$ and individual patients respond to different allergens. ${ }^{17,18}$ If the content of the specific allergens varies from one challenge material to another, that could affect the likelihood that certain patients would react at specific low doses and the estimation of the threshold dose. For example, the proportion of the major egg allergens Gal d 1 and Gal d 2 as a function of total protein would be higher in egg white than in whole egg. However, this consideration likely has little effect on the data for cows' milk and peanut because the proportion of specific allergens as a function of total protein would not change as a consequence of defatting or other processes. Also, in the case of peanut, little difference appears to occur in the specific allergen content as a function of variety or agronomic conditions. 19

Other features of the challenge trials were also variable, which introduces additional uncertainty. As already acknowledged, a few challenges, usually on the very youngest patients, were done single-blind or open rather than double-blind. Labial challenges are also occasionally used, although no such data are actually reported in Table I. In addition to the nature of the challenge material, as noted above, the nature of the challenge vehicle also varies, although this hopefully has limited effect on the results. The time interval between administration of the doses in a DBPCFC also varies. However, this factor likely did not have much effect on the estimation of the lowest provoking dose because the most sensitive patients reacted to the first dose administered. Clearly, the determination of the NOAEL and the estimation of the threshold doses would be much easier if the DBPCFCs were standardized with respect to all of the important factors.

Once a NOAEL is obtained (and it is possible to estimate a NOAEL from a LOAEL by applying some uncer- tainty factor), then the threshold dose could be estimated by the application of additional uncertainty factors. The primary source of remaining uncertainty would be with regard to human-to-human variability. Although data were obtained from DBPCFCs on more than 250 subjects with peanut, egg, and cows' milk, the range of lowest provoking doses was widely variable from one individual to the next. The range was several orders of magnitude for all 3 foods. But the most sensitive individual may not have been included in any of these trials. Therefore some uncertainty factor would need to be applied to the available data. However, because the risk assessment process was quite new to most of those attending this roundtable conference, no consensus was reached on the magnitude of the uncertainty factor that would be applied.

Some uncertainty will likely always remain regarding whether the threshold dose has been determined for the most sensitive individuals. Clinicians will never be completely certain that the most sensitive individual has been identified and tested. However, an analogy can likely be drawn to the infant formula industry, in which hypoallergenic infant formula based upon extensively hydrolyzed casein is safe for the vast majority of infants with milk allergy. Yet hypoallergenic infant formula is known to elicit adverse reactions in a very small minority of such infants. This analogy illustrates the difficulty in developing threshold doses, even with the application of uncertainty factors that will protect all allergic consumers. Instead, the goal should be to identify threshold doses that protect the vast majority of allergic consumers. Furthermore, the use of an uncertainty factor, as described earlier, may correct these concerns.

In summary, the threshold doses for peanut, egg, and cows' milk appear to be in the low milligram range or higher for most individuals with allergies to those particular foods. Thus these individuals can (and probably do) ingest foods, on occasion, containing lower amounts of their offending food without any untoward reactions. We recommend that international efforts be undertaken to establish threshold doses for commonly allergenic foods using standardized clinical challenge protocols and using as wide a range of affected patients as possible.

\section{REFERENCES}

1. Laoprasert N, Wallen ND, Jones RT, et al. Anaphylaxis in a milk-allergic child following ingestion of lemon sorbet containing trace quantities of milk. J Food Prot 1998;61:1522-4

2. Gern JE, Yang E, Evrard HM, Sampson HA. Allergic reactions to milkcontaminated 'non-dairy' products. N Engl J Med 1991;324:976-9.

3. Yunginger JW, Gauerke MB, Jones RT, et al. Use of radioimmunoassay to determine the nature, quantity and source of allergenic contamination of sunflower butter. J Food Prot 1983;46:625-8.

4. Jones RT, Squillace DL, Yunginger JW. Anaphylaxis in a milk-allergic child after ingestion of milk contaminated kosher-pareve-labeled 'dairyfree' dessert. Ann Allergy 1992;68:223-7.

5. Hourihane JO'B, Kilburn SA, Nordlee JA, et al. An evaluation of the sensitivity of subjects with peanut allergy to very low doses of peanut: a randomized, double-blind, placebo-controlled food challenge study. J Allergy Clin Immunol 1997;100:596-600.

6. Hourihane JO'B. The threshold concept in food safety and its applicability to food allergy. Allergy 2001;56(suppl 67):86-90. 
7. Taylor SL, Lehrer SB. Principles and characteristics of food allergens. Crit Rev Food Sci Nutr 1996;36(suppl):S91-118.

8. Malmheden Yman IM, Eriksson A, Everitt G, Yman L, Karlsson T. Analysis of food proteins for verification of contamination or misbranding. Food Agric Immunol 1994;6:167-72.

9. Hansen TK, Bindslev-Jensen C. Codfish allergy in adults. Identification and diagnosis. Allergy 1992;47:610-7.

10. Bock SA, Sampson HA, Atkins FM, et al. Double-blind, placebo-controlled food challenge (DBPCFC) as an office procedure: a manual. J Allergy Clin Immunol 1988;82:986-97.

11. National Research Council. Risk assessment in the federal government: managing the process. Washington (DC): National Academy Press; 1983.

12. World Health Organization. Principles for the safety assessment of food additives and contaminants in food. Environmental Health Criteria 70. Geneva, Switzerland: World Health Organization; 1987.

13. Hall RL, Taylor SL. Food toxicology and safety evaluation: changing perspectives and a challenge for the future. Food Technol 1989;43:270-9.
14. Burks W, Sampson HA, Bannon GA. Peanut allergens. Allergy 1998 ; 53:725-30.

15. Langeland $T$. A clinical and immunological study of allergy to hen's egg white. Ill. Allergens in hen's egg white studied by crossed radio-immunoelectrophoresis (CRIE). Allergy 1982;37:521-30.

16. Savilahti E, Kuitunen M. Allergenicity of cow milk proteins. J Pediatr 1992;121:S12-20.

17. Rabjohn P, Helm EM, Stanley J, et al. Molecular cloning and epitope analysis of the peanut allergen Ara h 3. J Clin Invest 1999;103:535-42.

18. Sicherer SH, Sampson HA. Cow's milk protein-specific IgE concentrations in two age groups of milk-allergic children and in children achieving clinical tolerance. Clin Exp Allergy 1999;29:507-12.

19. Koppelman SJ, Vlooswijk RAA, Knippels LMJ, et al. Quantification of major peanut allergens Ara $\mathrm{h} I$ and Ara $\mathrm{h} 2$ in the peanut varieties Runner, Spanish, Virginia, and Valencia, bred in different parts of the world. Allergy $2001 ; 56: 132-7$. 